\title{
PSYCHOLOGICAL AND PEDAGOGICAL BASES FORMING OF PROFESSIONAL COMPETENCE OF THE FUTURE EXPERT
}

\section{Kostyuchenko O. V.}

\section{INTRODUCTION}

Increasing requests of the transformational socio-cultural environment to the professionalism of experts in all areas requires original methods and means of formation and development, production of original ideas, the flexibility of thinking and behavior, mobility, autonomy, opening to new forms of professional self-realization. A famous contemporary American philosopher Alvin Toffler determined that “... the world emerging quickly from the collision of new values and technologies, geopolitical relations, lifestyles, and means of communication requires completely new ideas and analogies, classifications, and concepts" ${ }^{\text {" }}$ based on the analysis of the phenomenon of the transformation of modern societies. This concept is based on the modern social paradigm - from technocratic to industrial, from industrial to informational due to the educational formation of developed countries. Undoubtedly, social integration processes and such areas of the social development as globalization, democratization, dissolution of the NATO Member Countries, the creation of a single information space, determine the requirement of the constant reformation and updating of the education system at all levels.

The implementation of high-quality and effective training at the present stage of development of higher education intends to create the conditions, innovative technologies, and techniques, the search for variative systems, and models for the formation, development, and selfrealization of a competent specialist. In our opinion, increasing attention to forming, the development, and self-fulfillment of the professional competence of the future specialist is associated with the following indicative properties: readiness to professional self-realization, further personal and creative development, active participate in society; the ability to operate with such technologies, knowledge, and information that meets the needs of the information society, preparation for new roles in this society; readiness to change and adapt to the new needs of the labor

\footnotetext{
${ }^{1}$ Тоффлер Е. Третя хвиля. Київ: Вид. дім «Всесвіт», 2000. С. 14.
} 
market, to actively act and interact with the technological community, to make quick decisions, to study throughout life, etc.

According to the analysis of the experience of educational systems of many progressive countries, one of the ways to update the content of education and teaching technologies, aligning them with modern needs, integration into the educational global space is the orientation of educational programs to a competent approach and the creation of effective mechanisms for its introduction.

The problem solution of the formation and enhancement of the professional competence of specialists is represented in the works which are devoted to the professional training of specialists (V. Andrushchenko, M. Yevtukh, I. Zyazyun, V. Kremen); the concepts of the characteristics of professional activity (B. Ananiev, L. Vygotsky, S. Kalmykova, N. Menchinskaya, S. Rubinstein, etc.); the psychological and pedagogical theory and practice of European teachers (V. Doll, J. Deller, J. Callahan, J. Perret, G. Halas, etc.) and psychologists (L. Karpov, T. Kovaleva, N. Lobanova, L. Mitina, A. Makarova, E. Ogarev, O. Polunina, V. Slastonin, M. Choshanov, etc.).

Therefore, it is appropriate to state that the theoretical and practical process of forming professional competence of future specialists and its components in the process of study is insufficiently studied. There is a set of unstudied aspects of the mentioned problem especially the psychological aspects of professional competence development by means of project activity, creative and adaptive potential of teaching as a process of mastering various social experience and development of new models of behavior, and changes in value orientations, emergence of new cultural needs, and interests are not sufficiently specified.

The purpose of this publication is to do a comprehensive and integrated analysis of the psychological components of the formation of the professional competence of future specialists especially the realization of the creative and adaptive potential of learning by means of project activity, based on local and foreign experience which will further increase the level and quality of training and readiness for future professional activities.

\section{The competency approach to the formation of professionalism of a future specialist}

In the scope of this article, considerable interest is formed by scientific papers in which psychological approaches to the formation of professional competences of a future specialist are represented at the 
present stage of research. Among the many definitions of the DeSeCo project (Definition and Selection of Competencies, 1997), the definition of competence is fully represented. This is the ability to successfully meet individual and social needs, act and perform tasks. Each competency is built in the combination of mutual relevant cognitive attitudes and practical skills, values, emotions, behavioral components, knowledge, and skills, all that can be mobilized for active action ${ }^{2}$.

The substantive characteristics of the category "professional competence" as indicators of the level of professional training of a future specialist are showed in detail in the following researches: the concepts of "competence" and "capacity" in foreign and national scientific papers (K. Osadcha) ${ }^{3}$; the interpretation of competence as an approach to knowledge - a method for solving life problems, making decision in various spheres of human life, general ability based on knowledge, experience, values acquired through education, upbringing, integration into the space of social and cultural relations, interpersonal integration, and communication (I. Yermakova, G. Nesen, L. Sokhan) ${ }^{4}$; the formation method of the communicative competence of the future leader and manager (V. Bondarenko, L. Gren, Y. Panfilov) ${ }^{5}$; the definition of the competence components as properties (V. Kovalchuk, N. Kuzmin) ${ }^{6}$, productive-activity characteristics of education (O. Pometun) ${ }^{7}$, characteristics and abilities of people allowing them to achieve personally meaningful goals regardless of their nature and the social structure in which they live and work (D. Raven) ${ }^{8}$, the maturity of a person is based on professional activity (A. Markova) ${ }^{9}$; searching of ways formation and use of professional competence of future specialists; the development of methods of "general program competences" and knowledge based on "graduation" requirements

\footnotetext{
${ }^{2}$ Definition and Selection of Competencies. Theoretical and Conceptual Foundations (DESECO). Strategy Paper on Key Competencies. An Overarching Frame of Reference for an Assessment and Research Program - OECD (Draft).

${ }^{3}$ Осадча К. П. Аналіз понять «компетенція» та «компетентність» у зарубіжній та вітчизняній науковій літературі [Електронний ресурс]. Педагогічний дискурс. 2011. Режим доступу до ресурсу : file://C:/Users/Валерa/Desktop/peddysk_2011_9_61\%20(2).pdf.

${ }^{4}$ Життєва компетентність особистості / За ред. Л. Сохань, І. Єрмакова, Г. Несен. Київ, 2003. 250 с.

${ }^{5}$ Панфілов Ю. І., Бондаренко В. В., Грень Л. М. Методика формування комунікативної компетентності майбутнього лідера-менеджера. Теоретичні та прикладні аспекти дослідження феноменів лідерства, управління та розвитку соціального об 'єкта. 2016. №2. С. 10-19.

${ }^{6}$ Ковальчук В. В. Сутнісно-змістовна характеристика категорії «професійна компетентність» як показника рівня фахової підготовки студентів. Проблеми інженерно-педагогічної освіти. 2007. № 18-19. C. 84-88.

${ }^{7}$ Компетентнісний підхід у сучасній освіті: світовий досвід та українські перспективи: Бібліотека 3 освітньої політики / Під заг. ред. О. В. Овчарук. Київ : «К.І.С.», 2004. 112 с.

${ }^{8}$ Равен Дж. Компетентность в современном обществе. Москва: Когито-Центр, 2002. 395 с.

${ }^{9}$ Маркова А. К. Психология профессионализма. Москва: Знание, 1996. 308 с.
} 
of students; realization of education competencies in K-12 system (C. Sturgis) ${ }^{10}$; the professional competence as a way of being; an existential ontological perspective (J.Sandberg) ${ }^{11}$; educational competencies or education for professional competence (M. Hoverts) ${ }^{12}$; the expert assessment of professional competence (E. Dannefer) ${ }^{13}$; definition and evaluation of professional competence (R. Epstein) ${ }^{14}$; assessment of competence in the field of professional technical characteristics of various disciplines and professions (P. Wimmers) ${ }^{15}$.

There are still discussions on defining the content of the concepts "competence”, "capacity", their correlation, and the existence of different approaches to the classification of key competencies.

The term "competence approach" means the orientation of the educational process to the formation and development of the key (standard, basic), substantive competences of the individual; the gradual reorientation of the dominant educational paradigm with the prevailing translation of knowledge, the formation of skills for creating the conditions for mastering a complex of competencies which signify potential, ability to survive, and stable livelihoods in the conditions of modern multidimensional sociopolitical, market-economic, information, and communication-intensive space (G. Selevkov). O. Novikov believes that this approach is based on the concept of competences as a basis for the formation of students' ability to solve important learning activities and upbringing of the individual as a whole ${ }^{16}$. The result of this process will be the formation of general competence as a set of key competencies and an integrated personality trait that includes its knowledge, skills, attitudes, experience, and behavioral models. The competent approach in education is related to personally oriented and active approaches to learning, since it concerns the personality of the future specialist and can be implemented

${ }^{10}$ Sturgis, C. Implementing Competency Education in K-12 Systems: Insights from Local Leaders. CompetencyWorks Issue Brie [Електронний ресурc]. International Association for K-12 Online Learning. 2015. Режим доступу: http://files.eric.ed.gov/fulltext/ED557750.pdf.

11 Sandberg, J. Professional competence as ways of being: An existential ontological perspective. Pinnington. Journal of Management Studies. 2009. T. 46. P. 138-170.

12 Govaerts, M. J. Educational competencies or education for professional competence?. Medical education. 2008. T. 42. №3. P. 234-236.

${ }^{13}$ Dannefer, E. F. Peer assessment of professional competence [Електронний pecypc] / [Е. F. Dannefer, L. C. Henson, S. B. Bierer, T. A. Grady-Weliky, S. Meldrum, A. C. Nofziger et al. ]. Medical education. 2005.

${ }^{14}$ Epstein, R. M., Hundert E. M. Defining and assessing professional competence. American Medical Association. All rights reserved. 2002. № 2. P. 226-235.

${ }^{15}$ Wimmers, P. F. Mentkowsk, M. Assessing Competence in Professional Performance across Disciplines and Professions. Los Angeles, CA, USA : Springer, 2016. 473 c.

16 Управління формуванням професійної компетентності магістрантів педагогіки вищої школи: теоретико-методичні засади : монографія. Київ : Дорадо-Друк, 2013. С. 18-16. 
and tested only by the implementation of a student a particular set of actions ${ }^{17}$.

Generally speaking, the concept of key competencies are determined as an ability of the individual to participate effectively in many social fields, contribute to improving the quality of society, and contribute to personal success that can be applied to many spheres of life. The key competencies consist of the most general concepts which should be detailed in a set of knowledge, proficiencies, skills, values, the educational fields, and life spheres of the individual. One of the most important theoretical generality of the discussion about the concept of key competencies is the definition of three categories of key competencies as a conceptual base by representatives of the Organization for Economic Cooperation and Development (OECD) - autonomous activity; interactive use of resources and ability to function in socially heterogeneous groups.

According to the integrated approach to defining three categories of key competencies "DeSeCo, 2002"18, the following criteria of abilities are distinguished:

- Autonomous action: the ability to protect and take care of the responsibility, rights, interests, and needs of others; the ability to draw up and implement plans and individual projects; the ability to act in a significant or broad context;

- Interactive use of tools: the ability to apply language interactively, symbolism, and texts; the ability to use knowledge and information literacy; the ability to apply (new) interactive technologies;

- Ability to function in socially heterogeneous groups: the ability to successfully interact with others; the ability to cooperate; the ability to solve conflicts.

According to the requirements of the preparation level of future specialists, the key competencies are integral characteristics of the quality of learning associated with their ability to purposeful meaningful application of a set of knowledge, proficiencies, skills, and attitude towards a particular interdisciplinary range of problems. They reflect the subject-activity component of general education and should provide a comprehensive achievement of its goals.

Consequently, we distinguish the following main features of the vital (key) competencies: polyfunctionality is revealed in solving various problems in different spheres of personal and social life; the state of being

17 Компетентнісний підхід у сучасній освіті: світовий досвід та українські перспективи: Бібліотека з освітньої політики / Під заг. ред. О. В. Овчарук. Київ : “К.І.С.”, 2004. С. 64.

${ }^{18}$ там само. С. 10-11. 
a super object and interdisciplinary, that is implemented in various spheres of life; multidimensionality due to the full involvement and development of all components of the personal (self-knowledge, selfdetermination, self-esteem, and self-education), effective, cognitive, and creative sphere.

The goal of the competent-oriented education is becoming highly educated, developed and creative, capable of self-education and selfdevelopment of an individual. The project activity provides the possibility to obtain the appropriate experience and ability which is an instrument that creates unique preconditions for the development of key competencies (social, multicultural, informational, and communicative, etc.) and comprehends the new things independently by the individual.

\section{The project activity is an instrument for the formation and implementation of professional and vital (key) competencies}

The project activity is the strategic instrument of development in various spheres of personal development. The integral concept is based on the interaction of economic, technological, cultural, socio-psychological, and creative aspects. In this context, it is important to study the features: the realization of the project activity (M. Gurevich, A. Kopernik, I. Lerner, N. Matiash, V. Symonenko, I. Sasova, M. Romanovska, etc.), the use of the method of projects in management (O. Marmazi, I. Lyakhov, V. Glazycheva, I. Yermakova, V. Sidorenko, I. Shendrik, etc.), the project education as a means of forming the project method of engagement with the world (Z. Rubtsev, V. Zimova, H. Nechaev, $\mathrm{V}$. Sidorenko, etc.). One of the urgent tasks of the modern stage of development of the educational system which is showed in numerous attempts to improve it is the formation of a specialty of future specialists especially in the psychological and pedagogical sphere, of the project activity, and elements of the project culture.

The formation of the professional self-development of the project activity specialists allows focusing on personal development, ability to possess cognitive knowledge of a higher level, social significance of activity, ability to self-improvement, formation of professional competencies, professional and social orientation, effective analysis of professional activity, and independence of professional qualification improvement future specialists.

Before analyzing the peculiarities of the project activity as professional competence, one should give examples from the psychological 
literature of the definitions of "professional competence" which explain its essential characteristics, principles, and concepts which it is based on ${ }^{19}$. Thus, professional competence is considered as an individual characteristic of the degree of compliance with the requirements of the profession which is defined as a combination of mental qualities; a mental state that allows someone to act independently and responsibly (effective competence); the possession skills and ability to perform certain labor functions; personally professional, socially significant qualitative characteristic of a specialist who can use knowledge, skills, abilities not only for professional activity but also for understanding social significance and moral consciousness of activity; professional-status opportunities concerning state, social, and personal powers in professional activities; possession of the relevant competence including the personal attitude to him/her and a subject.

At the same time, the ability to project activities as competence includes a set of interrelated personality traits (knowledge, skills, abilities, work method), that are regarded with a certain range of objects, processes, and effective actions. It includes a concept that of three aspects: a problem-practical aspect which is an adequate understanding of the situation, the effective implementation of goals, objectives, and norms; a semantic aspect which is an adequate understanding of the production situation in a more general socio-cultural context; a value aspect which is the ability to the correct assess of a situation, its point, goals, tasks, and norms from the perspective of general and its significant values, etc.

Summing up the different views on the problem of the formation of vital ${ }^{20}$ and professional competencies, the necessary qualities and skills should be identified which the criterion of formation is considered the ability to project activities: flexibility, mobility, competitiveness, ability to engage into dynamic society, represent himself at a labor market; the ability to use knowledge for solving life problems; generation of new ideas, making non-standard decisions, and responsibility for consequences; ability to communicate, ability to work in a team, prevention and resolution of conflict situations; the ability to obtain, analyze, interpret, transmit information obtained from various sources, apply it for the individual development and self-improvement; careful attitude

${ }^{19}$ Барченков Д. А. Психологическое содержание профессиональной компетентности менеджера полифункционального холдинга. Вестник Тамбовского университета. Серия Гуманитарные науки. 2007. № 4. С. 199-206.

${ }^{20}$ Срмаков I. Г. Феномен компетентнісно спрямованої освіти. Крок за кроком до життєвої компетентності та успіху. Київ: Лат і К, 2003. С. 6-8. 
towards his/her health and health of others as the highest value; the ability to choose among the many alternatives to the optimal solution.

The idea of incorporating project activities into the educational process was proposed by an American educator and philosopher John Dewey. It is arguable that the project method is a modern technology nowadays that promotes the effective formation of such key competencies as the future specialists: vocational and pedagogical, social-psychological, communicative, informational and communicative, general cultural, health-saving, civic, etc. It provides opportunities for engagement in research and searching, reinforcement of additional motivation and interest in educational-cognitive activities.

Based on the research of J. Raven proved that the key components of the development of psychological competence are the development environment where conditions for the identification and development of abilities are created, the ability of a future specialist to study deeply the peculiarities of the structure of the organization and institution, firms or companies where s/he works and the specifics psychological thinking of their employees; self-analysis of its activities in order to determine the effectiveness ${ }^{21}$.

It should be noted that the project activity in educational and professional activities is the environment conducive to the implementation and the development of the creative and leadership potential of the personality, forms social skills, abilities, and communicative culture. In addition, the project activity has the following universally recognized psychological features as the intellectual-capacity nature of the subject area of the projects; stipulation of the success of the project with properties of a customer; a high degree of individualization for the customer which requires a full cooperation with him/her; a rapid loss of relevance of the results; high probability of inclusion in new, previously unavailable works that need adaptation or creation of a methodology, technology, and management system; demanding qualification of specialists as managers and executors; a high level of communicative and corporate culture, etc. ${ }^{22}$.

The concept of a projection is defined as a process that gives rise to changes in the artificial environment (J. Johnson) ${ }^{23}$, which develops the design skills of its participants, the ability to navigate the information

\footnotetext{
${ }^{21}$ Равен Дж. Компетентность в современном обществе. Москва: Когито-Центр, 2002. 395 с.

${ }^{22}$ Костюченко О. В., Л. П. Дихнич. Психологія ефективності фахівця індустрії моди. Київ: Ліра, 2016. 464 c.

${ }^{23}$ Джонс Дж. Методы прогнозирования. М.: Мир, 1986. 524 с.
} 
space, to practice knowledge, forms the ability to independently construct his/her activities (L. Vasilevskaya) ${ }^{24}$; a special type of intellectual activity, the distinctive feature of which is the perspective orientation towards a practically directed research (I. Isaev) ${ }^{25}$; a complex activity that features signs of auto-didactics (automatic assimilation by designers without a specially defined didactic task by organizers of new concepts, new ideas about different spheres of life production, personal, socio-political relations, a new understanding of the content of life changes); awareness of the role of "Adult” and responsibility for their own lives (Y. Khrikov) ${ }^{26}$; an independent activity that involves the presence of such a stage as forecasting (a specially organized study aimed at obtaining information on the development of an object) (A. Tsymbalaru) ${ }^{27}$; type of activity that synthesizes elements of the game, cognitive, value-orientational, transformative, professional-labor, communicative, educational, theoretical practical activity (O. Kobernik) ${ }^{28}$; creative, innovative activity since it is always aimed at creating an objective and subjectively new product (A. Leontiev) ${ }^{29}$.

We defined the project in educational activity as a complex of interrelated, focused, consistently oriented, psychological and pedagogical measures in creation of a different kind of items on the basis of traditional and contemporary trends in psychology and pedagogy in limited resources (financial, labor, and material) and specify the terms of beginning and ending. The project is unique as a learning method ${ }^{30}$, which is revealed in targeting the achievement of the goals of future professionals. It is effective in the formation and implementation of a significant number of educational and life competencies which are irreplaceable in the formation of experience.

The project activities include the following key skills as problemsolving, job scheduling, search, compilation, information processing, and presentation of work results. The project activity serves as a way

\footnotetext{
${ }^{24}$ Василевська Л. С. Проектна діяльність методиста як засіб удосконалення професійної майстерності педагогів [Електронний ресурс]. Наукові записки [Ніжинського державного університету ім. Миколи Гоголя]. Сер.: Психолого-педагогічні науки. 2012. № 6.

${ }^{25}$ Исаев И. Ф. Развитие профессионально-педагогической культуры преподавателя в условиях модернизации педагогического образования. Педагогіка та психологія. Харків, 2006. Вип. 29. С. 63-72.

${ }^{26}$ Хриков С. М. Педагогічні умови як складова наукових знань. Шлях освіти. 2011. № 2. С. 11-15.

${ }^{27}$ Цимбалару А. Д. Семантика понятійного апарату проблеми педагогічного проектування. Нова педагогічна думка. 2009. № 3. С. 30-35.

${ }^{28}$ Коберник О. М. Проективна педагогіка і національна школа. Шлях освіти. 2000. № 1. С. 7-9.

29 Леонтьев А. Н. Деятельность. Сознание. Личность. Москва : Политиздат, 1977. 304 с.

30 Власюк О. Проектна діяльність - перспектива розвитку особистості. Проектна діяльність у ліцеї: компетентнісний потенціал, теорія і практика / за ред. С. М. Шевцової, І. Г. Єрмакова, О. В. Батечко, В. О. Жадька. К. : Департамент, 2008. 520 с.
} 
of developing creativity, independence, the desire for an ideally-perspective transformation of the world through creative actions and operations in the process of creating a specific thing which is a project of the ideal and the real ${ }^{31}$. It should be noted that project training contributes to solving such psychological and pedagogical goals as creating positive motivation during training; the formation of mental skills, the development of operation logical thinking; the formation of methods of group work in a team, etc. In addition, the implementation of each kind of projects ${ }^{32}$ requires the activation of various components of the psyche, especially Exploring components (biological, physiological, technical, solution of historical or literary problems) need a well-thought structure, completely subordinated to the logic of research and have the structure of definition of the research methodology, i.e. the subject of the research, argumentation of its relevance, subject and object, tasks and methods of the research, the formulation of hypotheses, ways of problem solving; Creative components (productive and creative) are related to work activity (design, creation of a model, care of plants, and animals) do not have a detailed structure of the joint activity of participants. It develops subordinate to the final result and the form of its presentation (an activities list, a video, a holiday, etc.); Information components aimed at collecting information about an object, phenomenon, for acquaintance the project participants with this information, its analysis, and generalization of the facts; Practical (consumer) components (preparation of excursions, service provision, and organization of leisure) are solving practical tasks of a "customer" of a project and as a result, the development of a visual guide, a layout, an instrument, an equipment, and recommendations for their usage; Gaming (role-playing) components are a graphic representation of real processes and phenomena in stage forms, game situations, as a result, simulation of a real object.

The object-subjective relationship plays a decisive role in the psychological and pedagogical design. Their purpose is to achieve a positive psychological and progressive cultural effect from the project's implementation as a product, item, and action, as well as a means and an instrument of mass communication. Ten urgent in 5 years skills were identified at the Annual World Economic Forum in Davos (Switzerland, 2016) which gathered more than 2,500 top-level leaders including more

\footnotetext{
${ }^{31}$ Хоружа Л. Проектна культура вчителя: етичний компонент. Шлях освіти. 2006. № 4. С. 11-15.

32 Власюк О. Проектна діяльність - перспектива розвитку особистості. Проектна діяльність у ліцеї: компетентнісний потенціал, теорія і практика / за ред. С.М. Шевцової, І.Г. Єрмакова, О.В. Батечко, В.О. Жадька. К. : Департамент, 2008. 520 с.
} 
than 50 leaders of state and government and about a thousand heads of multinational companies. We define an integrated multilevel problem solving, critical thinking, cognitive flexibility, creativity, human ability to manage, interaction, emotional intelligence, the thought formation and making a decision, customer-focused, negotiating skills as a strategic instrument for the project activity.

It should be pointed out that the successful accomplishment of the project-based learning activities (project activities) depends on the efficiency of the interaction between the subjects engaged in psychological and pedagogical practices. Such practices relate to the designing process, producing and distributing the objects of activities: the tendency, the standards and the product (manuals, scientific and popular magazines, newspapers, educational and scientific-methodical materials, presentations, training, workshops, different types of course formats: lectures, seminars, practical, etc.). The profitable application of the project activities also depends on "producers" and "users" of the project products, which multiply the subjects mentioned above; and "distributors" - mass media and PR-aspects (magazines, TV and show programs, presentations, advertising, TV, authoritative personalities, etc.). The following conditions are required for the successful fulfillment of the educational project such as the meaningful research issue; skillful formulation of the key and thematic questions; practical significance of the expected results (publication, poster, anthology, presentation, etc.); independent work; structuring the substance of the project (stages, tasks, distribution of roles, etc.); the usage of research methods; application of computer technologies (for information search, communication with the other project participants, generation of the project's final product).

Now we select the key-points of the follow-up mechanism of the project's technology that are conditions for self-realization of the specialist's personality, and the development of his/her potential capabilities. These conditions can be listed as follows: (1) the organization of stimulating energy flow and information space (content, socio-cultural, educational) for potential development; (2) the organization of various types of activities that are conditions for self-realization of the future specialist. They consist of social communication, socially profitable actions, game, physical and recreational, educational and cognitive, research, artistic and aesthetic, tourist-local lore, scientific and technical, decorative and applied, ecological and naturalistic activities, etc.; (3) the organization of effective communication that creates situation for 
social development of a specialist and shaping a positive "I-concept" plus a culture of dialogue based on interactive forms of practice; (4) systematic psychological support for solving personal problems of the specialists, promoting their self-identification, self-determination and self-actualization; (5) increasing the level of professional skills, projective culture within the circle of the psychological and pedagogical personnel; (6) awareness of his/her personal social responsibility, and constant personal and professional growth.

Thus, a projection is rather fundamentally different subjective than an objective form of participation in social activities and as such, it is a specific individual creative process, which requires from every person original new solutions and at the same time that is a process of collective creativity. The most important achievements obtained during the project activities are shaping the ability to research, the development of public speaking skills, capacity to present the result of his/her work (project product) and affirmation of personal competence, the ability to communicate briefly and convincingly about himself/herself and his/her work. The projection can become a means of social and intellectual creative self-development of all subjects of education (students, teachers, and administrators of educational institutions), and in the narrower sense that is a means for the development of projective abilities.

\section{The creative and adaptive potential of the projective education system}

We assign to the structure of creative and adaptive potential of projective training the following components: motivational-orientation that determines the direction toward the goal and its achievement; cognitive that includes individual-perceptual, mnemonic, thinking strategies and tactics of solving actual tasks; emotional-volitional that describes emotional-imaginative experience and volitional regulation of creative quest plus perception of himself/herself as "the center of activity" in solving creative tasks; communicative that identifies the specificity of interpersonal communication, and ability to interact productively with a group while solving together creative tasks; reflexive that is a personal assessment of his/her capabilities, plus a process and results auditing. It is important to understand that the result of the future specialist's adaptation (i.e., a process of branching out into a new area of responsibility and social environment) is his/her social and cultural development as the most important mechanism of individual socialization 
(D. Andreev, S. Bezklubenko, L. Bueva, Y. Kulyutkina, A. Rean). It presupposes a personal active attitude and leads to personal changes (I. Miloslavova). The specific pedagogical studies attempt to determine "the adaptive skills" definition but in most of them, the authors only briefly address this problem (G. Ball, O. Gura, I. Zimnya, N. Kuzmina, etc.). Most authors (F. Berezin, M. Dmitrieva, L. Mitina, etc.) examine the professional adaptation in the context of the person's effective functioning. The adaptation is simultaneously a process of mastering a variety of social experiences and development of the new models of behavior, changing value orientations, the emergence of the new cultural needs, and interests.

Among the many educational functions, we focus on those that release his/her creative and adaptive potential. Thus, for keeping knowledge and information, and distribution (i.e., extension or transfer of information, or interconnection of knowledge) the following methods are effective: method of cases (active learning method based on the consideration of specific business situations, exceptional occurrences and cases, and aimed at the formation of the needed professional and personal qualities, skills, and capacities) ${ }^{33}$, case method, the method of specific situations, the method of situational analysis (a teaching technique that uses a description of real economic, social and business situations), in which the student has to be active, to achieve something or to discover, to create, to repeat, to shape skills. Also other functions are important such as control of understanding and students' actions as regards their accomplishment (made/did not made, procrastination, etc.); assessing the student's understanding and outcomes in order to identify the mistakes and problems (how well the student understands, how he/she succeeds); answers to the questions, explanations, interaction with a student or a group; assessment of the student's psychological state, his/her ability to overcome obstacles, detecting frustrations and problems; influence on the student's motivation to climb the steep hill; constant self-education, self-development, reflection and awareness of his/her problems.

There are plenty of methods that are based on the integration of creative-cognitive activities, which are divided into instrumental and personality methods. Instrumental methods provide a group problem solving and assist in searching a certain way in shaping his/her mental activities for solving a specific task; determine the algorithm of actions or

\footnotetext{
${ }^{33}$ Федорчук Е. І. Сучасні педагогічні технології. Кам’янець-Подільський : Абетка, 2006. С. 57.
} 
a set of general rules (heuristics) the usage of which helps get solution with sufficient probability. The instrumental methods include Brainstorming (A. Osborne), Synectics (W. Gordon), worksheets, "Morphological analysis" (F. Zwicky), the algorithm for solving inventive tasks, "Maieutics" (Socrates dialogues), CARUS (Combining Analogy Reconstructing Universal Strategy) a creative search method (V. Moliako), etc. The personality methods impact on personal behavior, build-up self-confidence, and stir feelings of his/her power raise awareness of the infinite opportunities of self-improvement in any sphere of life. These methods are designed for personal development training and aimed at strengthening the individual's ability to think autonomously and independently, developing special skills, and creativity. These techniques include: group dynamics (B. Holleran), transcendental meditation (F. Travis), method of developing personal integrity (R. Pivi), bodyoriented, cognitive, rational-emotive (A. Beck and A. Ellis), assertive technique, gestalt-technique, an awareness of the needs, etc. ${ }^{34}$.

In professional activities, communication plays a fundamental role and its effectiveness is interdependent with adaptive and creative processes. That fact presupposes the use of such an educational system that is aimed at building the socio-psychological competence. This competence implies the knowledge of group communication factors, understanding strategy and tactics of communication partners, mastering dialogue skills, and also the ability to use them in a specific communicative situation. Currently, the different methods of active social psychological learning (discussion, training, games, etc.) are freely distributed in the system of specialists training in those areas of professional activity, where the process of communication plays a leading role (Y. Yemelianov, V. Morgun, T. Yatsenko, etc.). In the broader sense of the word, the sociopsychological workshop is understood as the practice of psychological influence, which is based on active methods of group work. Such methods use original approaches for acquiring techniques in the sphere of communication, work, personal development, and correction, namely, mastering a certain socio-psychological knowledge related to the optimization of interpersonal communication, the development of communicative, reflexive and analytical abilities and skills, and increasing socio-psychological competence. In professional activities, communication plays a fundamental role and its effectiveness is interdependent with

${ }^{34}$ Костюченко О. В., Л. П. Дихнич. Психологія ефективності фахівця індустрії моди. Київ: Ліра, 2016. $464 \mathrm{c}$. 
adaptive and creative processes. That fact presupposes the use of such an educational system that is aimed at building the socio-psychological competence.

This competence implies the knowledge of group communication factors, understanding strategy and tactics of communication partners, mastering dialogue skills, and also the ability to use them in a specific communicative situation. Currently, the different methods of active social psychological learning (discussion, training, games, etc.) are freely distributed in the system of specialists training in those areas of professional activity, where the process of communication plays a leading role (Y. Yemelianov, V. Morgun, T. Yatsenko, etc.). In the broader sense of the word, the socio-psychological workshop is understood as the practice of psychological influence, which is based on active methods of group work. Such methods use original approaches for acquiring techniques in the sphere of communication, work, personal development, and correction, namely, mastering a certain sociopsychological knowledge related to the optimization of interpersonal communication, the development of communicative, reflexive and analytical abilities and skills, and increasing socio-psychological competence.

The creative and adaptive potential of training is released in the usage of such means and techniques which promote the acquisition of professional behavior skills particularly various types of reflections that form the basis for the development of self-regulation and selfimprovement abilities of the future manager. Among the reflexive environment organizational means, the game is the most commonly used method (that includes organizational-active, imitative, group dynamic, intellectual, and creative games) which promotes creative thinking and self-expression, self-analysis, and awareness of himself/herself as a person and individual and a specialist. Playing diverse and meaningful for learning situations and their analysis allow students to taste for themselves the whole psychological and pedagogical efficient and inefficient outcome of their actions.

The group debate and discussion are the leading teaching methods that allow participants to receive feedback from others, to determine a personal orientation and their self-evaluations, and a level of achievements, etc. The advantage of keeping a self-observation diary is evident in stimulating creative processes, reducing internal stress, training research skills and self-regulation. The results of the educational process are 
evaluated by reliable criteria of effectiveness: self-reports of the group participants (in response to the questionnaire); changing the perception of oneself and others.

The special classes are original and focus on gaining the personal experience of the diverse influences of various means, methods, and techniques. Among many techniques a significant emphasis has been placed on painting, modeling with color, form, perfumes, tastes, sounds, and images. The creativity is stirred up by a whole system of motives, and the central stimuli are following: an attempt to perceive and express his/her emotions and an experience in a visible form; the need to communicate with others using his/her products; he endeavors to study the surrounding world through the symbolization of it in a special form and to design the image of the world and the personal professional brand in the form of drawings, compositions of sounds, fragrances, shapes, colors, and holistic images.

We select the following essential factors of the efficient education, for instance: the level of object-subject relations in educational activities, when the subject is the one who teaches, seeks changes (Teacher, Lecturer, Coach, Tutor, Instructor, etc.), but the object of teaching is one who is taught, whom a teacher tries to transform (Pupil, Protégé, Follower, Superseder, Heir, Adherent, Admirer, Disciple, etc.); the level of individualization when one takes into consideration the peculiarities of perception, processing, interpretation and reproduction of information, fundamental properties of the brain, namely, neuroplasticity (the ability of remodeling under the influence of experience and as a response to external impacts $)^{35}$, which requires a certain number of repetitions for the development of sustainable skills; the level of integration of full-fledged perception of various modalities, logical and figurative, creative thinking, memory, emotions and states, and conscious bodily reaction; learning "in the context" and "by reality" a new information and opportunity to evaluate the action practice immediately after finishing it and to receive feedback; stimulating positive emotions, creating an atmosphere of approval, joy and trust; presence a teacher who provides: 1) the identification, evaluation, and analysis of the previous iteration's mistakes (an iteration means organization of data processing in which the actions are repeated again and again); 2) new data that are needed but it was not recognized before the evaluation of previous iteration's results;

35 Дойдж Н. Пластичность мозга. Потрясающие факты о том, как мысли способны менять структуру и функции нашего мозга: пер. с англ. Е. Виноградовой. Москва : Эксмо, 2012. 540 с. 
3) recommendations for correction of the efforts in accord with the purpose of the next iteration.

The normal process of learning is honest, responsible and result oriented, and unlike imaginary learning (marketing, politics, ideology, logistics), it is a project training ${ }^{3637}$. The key elements of project training are the sense (Why it is necessary? How does it change his/her life? Why it is necessary to invest my time and your time? What are the positive results? From what negative traits he/she will be get rid of?), the best motivation is understanding the sense of it; the goal (What specific result do you want to achieve within the framework of the project?) should be lucid, measurable and fixed by the date; the term of undertaking (to present the result by the specified date); tasks (What he/she has to do for achieving the goal?); resources (material, intellectual, etc.); shortage, difficulties and problems; action (What did the student accomplish? And what is the quality of his/her results?).

The project training contributes to (1) cultivating students' independence and eagerness in gaining knowledge and in learning, (2) modifying the meaning of interaction from subordination to cooperation and partnership, (3) the development of relevant professional skills and experience together with teamwork skills. The future specialist should learn to achieve a good quality result by the date fixed overcoming the shortage of resources.

Thus, in the project training such important principles of modern education are realized as the achievement of the result, growth of competitiveness and efficiency, promotion, where the focus shifts from the essential issues to personal communication. Therefore the role of the Teacher is reduced to mentoring, instructing rather than creating and communicating the content. The typical role of the Teacher expands, when besides the role of the content Creator and lecturer, the role of the Mentor is added that includes putting forth a task, examining and evaluating the results, explaining things in which the student displayed ignorance, interpreting cases, promotion, responsibility for the pace, content, and quality. Plus the mentor assumes the role of tracker that comprises responsibility for the consequences and the final productivity. As a result, the student creates or participates in the creation of an important outcome for him/her and the market/society.

\footnotetext{
${ }^{36}$ Бордовская Н. В. Гуманитарные технологии в вузовской образовательной практике: теория и методология проектирования. Санкт-Петербург : РГПУ им. А.И. Герцена, 2007. 384 с.

37 Колесникова И. А., Горчакова-Сибирская М. П. Педагогическое проектирование / Под. ред. В. А. Сластенина, И. А. Колесниковой. 3-е изд. Москва: Академия, 2008. 288 с.
} 
At the same time, the teaching of designing or project education is a means of constructing a designing method of interaction with the world as noted by well-known home scientists (V. Rubtsiv, V. Zimova, N. Nechaev, V. Sidorenko, etc.). One of the important tasks of educational system contemporary stage development is to build up students in understanding the project activity basics, and elements of the designing culture. For a future specialist the project training is the way for development of the personal creative potential and his/her self-realization; it is the developing environment that forms social abilities and skills plus facilitates the process of acquiring the life experience; it is functioning as a means for verifying the correspondence of the personal experience with the needs of a person to play an active role in society; it is acting as a creative report on the level of leadership competence.

Thus, it is possible to underline the following properties of the modern (relevant - important, essential, timely, appropriate) learning: accessibility, continuity, flexibility, productivity, competitiveness, focus on the development of pro-activity, initiative, and enterprise in a broader sense, and not just on mastering profession; it becomes: the most important valuable orientation; a way of achieving creative selfrealization and a high level of social hierarchy; leading daily and lifelong activity; traditional lecture format gives way to the project and problemoriented learning; changing models of education scaling (individual learning based on an individual plan and the availability of mentors for everyone will gradually replace the mass education); innovation of educational technologies (e.g., online education and the virtual environment, personification; modeling and prediction of a career based on the use of artificial intelligence, and Big Data approaches; a complete model of virtual reality, the maturity of a person and improvement of his/her cognitive abilities and possible cyborgization).

These properties will require the development and implementation of technologies: scalable, accessible, remote, full mentoring for everyone; likewise modeling and forecasting of an individual learning trajectory, which becomes synonymous with a career, in fact, it is modeling of destiny; further training protocols based on neuroplasticity are able to change the topology of the neuron network of the brain, and thus dramatically increase the speed and depth of training. 


\section{CONCLUSIONS}

In general, the analysis of scientific literature on the studies of this issue demonstrates that such specific direction of study and research as to the components of professional competence of the future specialists, namely, the ability to designing is insufficiently highlighted by both home and foreign authors and scholars.

Thus, we identified the main essential characteristics of the project activity such as (1) constructiveness and productivity, which contribute to the solution of vital problems and the achievement of the final result in the process of goal-setting, planning and implementation of the project; (2) a unique way of practice related to the prediction of the future, and creation of its ideal image including plan completion and evaluation of the consequences of accomplishing the plans; (3) the factor in the formation and development of specific design skills, namely, problematization (finding and formulating problems and tasks); (4) goal-setting and planning activities; (5) self-analysis and reflection (self-examination of the success and efficiency of project completion); (6) the presentation of the product activities; (7) selection and use of optimal technology for producing the designed product; (8) conducting the research (analysis, synthesis, putting forth a hypothesis, specification of details and generalization); (9) a tool for creating unique prerequisites for personal and professional selfdevelopment, the acquisition by the future specialists such skills as orienting in the educational sphere, generalizing theoretical knowledge and integrating it into professional skills, independent constructing and integrating his/her activities for achieving progressive innovations in the chosen professional environment; (10) one of the most promising components of the professional achievements as the specialists, when conditions for his/her creative self-development and releasing creative potential are constructed, professional competences are shaped, i.e., multicultural, linguistic, informational, political, socio-psychological, etc.

It is determined that the creative and adaptive potential of the project training 1 ) is released in the complex, dynamic and diverse psychological process of internal and external transformation of the motivational sphere and the usual forms and methods of activity, developing the needed complex of skills, abilities and habits for practicing new types of activities and turning them into a habit; 2) provides adaptation to the socio-cultural environment, adequacy, behavioral flexibility, accuracy of thinking, emotional balance and purposefulness. It is a prerequisite for releasing creative possibilities of the manager in a new, and unusual conditions. 
The perspective of further research. The main task of the future research is the construction of a model for the formation of professional competence of the future specialists in the conditions of higher educational institutions using psychological approaches based on the practical application of the modern model of education in foreign countries from the competent approach point of view.

\section{SUMMARY}

In the article, the essential features of the actual training of future specialists are theoretically analyzed. The factors of its efficiency, in particular, key elements, principles, functions, means, and methods of project training are examined, and especially the use of the method of projects from the competence approach point of view. It is found out that the creative and adaptive potential of the project training: 1 ) is released in a complex, dynamic and diverse psychological process of internal and external transformation of the motivational sphere and the usual forms and methods of activities; 2) provides adaptation to the socio-cultural environment, adequacy, behavioral flexibility, accuracy of thinking, emotional balance and purposefulness; 3) is a prerequisite for releasing the creative potential of a future specialist in a new and unusual conditions. The technologies of the project activity are mentioned. The main psychological and pedagogical purposes of project activity implementation are described by various types of studies on designing. The main components of the mechanism of implementation of the project technology are explained. They are conditions for self-realization of the specialist's personality, and development of his/her potential capabilities. Emphasis is placed on the fact that the implementation of the educational projects involves the integration of cognitive, research, gaming, and creative activities aimed at obtaining independent results in correspondence with psychological and pedagogical support.

\section{REFERENCES}

1.Барченков Д. А. Психологическое содержание профессиональной компетентности менеджера полифункционального холдинга. Вестник Тамбовского университета. Серия Гуманитарные науки. 2007. № 4. С. 199-206.

2. Бордовская Н. В. Гуманитарные технологии в вузовской образовательной практике: теория и методология проектирования. Санкт-Петербург : РГПУ им. А.И. Герцена, 2007. 384 с. 
3. Василевська Л. С. Проектна діяльність методиста як засіб удосконалення професійної майстерності педагогів [Електронний ресурс]. Наукові записки [Ніжинського державного університету ім. Миколи Гоголя]. Сер.: Психолого-педагогічні науки. 2012. № 6. Режим доступу: http://nbuv.gov.ua/j-pdf/ Nzspp _2012_6_32.pdf.

4. Власюк О. Проектна діяльність - перспектива розвитку особистості. Проектна діяльність у ліцеї: компетентнісний потенціал, теорія і практика / за ред. С.М. Шевцової, І.Г. Срмакова, О.В. Батечко, В.О. Жадька. К. : Департамент, 2008. 520 с.

5. Джонс Дж. Методы прогнозирования. М.: Мир, 1986. 524 с.

6. Дойдж Н. Пластичность мозга. Потрясающие факты о том, как мысли способны менять структуру и функции нашего мозга: пер. с англ. Е. Виноградовой. Москва : Эксмо, 2012. 540 с.

7. Срмаков I. Г. Феномен компетентнісно спрямованої освіти. Крок за кроком до життєвої компетентності та успіху. Київ: Лат і К, 2003. С. 6-8.

8. Життєва компетентність особистості / За ред. Л. Сохань, I. Срмакова, Г. Несен. Київ, 2003. 250 с.

9. Исаев И. Ф. Развитие профессионально-педагогической культуры преподавателя в условиях модернизации педагогического образования. Педагогіка та психологія. Харків, 2006. Вип. 29. С. 63-72.

10. Коберник О. М. Проективна педагогіка і національна школа. Шлях освіти. 2000. № 1. С. 7-9.

11. Ковальчук В. В. Сутнісно-змістовна характеристика категорії «професійна компетентність» як показника рівня фахової підготовки студентів. Проблеми інженерно-педагогічної освіти. 2007. № 18-19. С. 84-88.

12. Колесникова И. А., Горчакова-Сибирская М. П. Педагогическое проектирование / Под. ред. В. А. Сластенина, И. А. Колесниковой. 3-е изд. Москва: Академия, 2008. 288 с.

13. Компетентнісний підхід у сучасній освіті: світовий досвід та українські перспективи: Бібліотека з освітньої політики / Під заг. ред. О. В. Овчарук. Київ : «К.І.С.», 2004. 112 с.

14. Костюченко О. В., Л. П. Дихнич. Психологія ефективності фахівця індустрії моди. Київ: Ліра, 2016. 464 с.

15. Леонтьев А. Н. Деятельность. Сознание. Личность. Москва : Политиздат, 1977. 304 с.

16. Маркова А. К. Психология профессионализма. Москва: Знание, 1996. $308 \mathrm{c.}$ 
17. Осадча К. П. Аналіз понять «компетенція» та «компетентність» у зарубіжній та вітчизняній науковій літературі [Електронний ресурс]. Педагогічний дискурс. 2011. Режим доступу до ресурсу : file://C:/Users/Валера/Desktop/peddysk_2011_ 9_61\%20(2).pdf.

18. Панфілов Ю. І., Бондаренко В. В., Грень Л. М. Методика формування комунікативної компетентності майбутнього лідераменеджера. Теоретичні та прикладні аспекти дослідження феноменів лідерства, управління та розвитку сочіального об'єкта. 2016. № 2. C. 10-19.

19. Равен Дж. Компетентность в современном обществе. Москва: Когито-Центр, 2002. 395 с.

20. Тоффлер Е. Третя хвиля. Київ: Вид. дім «Всесвіт», 2000. C. 14.

21. Управління формуванням професійної компетентності магістрантів педагогіки вищої школи: теоретико-методичні засади : монографія. Київ : Дорадо-Друк, 2013. 456 с.

22. Федорчук Е. І. Сучасні педагогічні технології. Кам'янецьПодільський : Абетка, 2006. С. 57.

23. Хоружа Л. Проектна культура вчителя: етичний компонент. Шлях освіти. 2006. № 4. С. 11-15.

24. Хриков С.М. Педагогічні умови як складова наукових знань. Шлях освіти. 2011. № 2. С. 11-15.

25. Цимбалару А. Д. Семантика понятійного апарату проблеми педагогічного проектування. Нова педагогічна думка. 2009. № 3. C. 30-35.

26. Шарко В.Д. Моніторинг як одна 3 умов реалізації акмеологічного принципу в педагогічній освіті. Вісник Херсонського державного технічного університету. 2001. № 2.

27. Ягоднікова В. В. Кейс-метод (Case study) як форма інтерактивного навчання майбутніх фахівців. Секиія «Педагогічні науки», підсекція № 5. [Електроний ресурс]. Режим доступу : http://www.rusnauka.com/1_NIO_2008/Pedagogica/25496.doc.htm.

28. Dannefer, E. F. Peer assessment of professional competence [Електронний ресурс] / [E. F. Dannefer, L. C. Henson, S. B. Bierer, T. A. Grady-Weliky, S. Meldrum, A. C. Nofziger et al.]. Medical education. 2005. Режим доступу: https://www.researchgate.net/profile/ Ronald_Epstein/publication/7782103_Peer_assessment_of_professional_ competence/links/0deec51586e8070ae0000000.pdf. 
29. Definition and Selection of Competencies. Theoretical and Conceptual Foundations (DESECO). Strategy Paper on Key Competencies. An Overarching Frame of Reference for an Assessment and Research Program - OECD (Draft).

30. Epstein, R. M., Hundert E. M. Defining and assessing professional competence. American Medical Association. All rights reserved. 2002. № 2. P. 226-235.

31. Govaerts, M. J. Educational competencies or education for professional competence? Medical education. 2008. T. 42. № 3. P. 234-236.

32. Sturgis, C. Implementing Competency Education in K-12 Systems: Insights from Local Leaders. CompetencyWorks Issue Brie [Електронний ресурс] / C. Sturgis. International Association for K-12 Online Learning. 2015. Режим доступу: http://files.eric.ed.gov/fulltext/ ED557750.pdf.

33. Sandberg, J. Pinnington, A. H. Professional competence as ways of being: An existential ontological perspective. Journal of Management Studies. 2009. T. 46. P. 138-170.

34. Wimmers, P. F., Mentkowsk, M.. Assessing Competence in Professional Performance across Disciplines and Professions. Los Angeles, CA, USA: Springer, 2016. 473 p.

\section{Information about the author: Kostyuchenko O. V.} Doctor of Psychological Sciences, Associate Professor, Assistant Professor at the Department of Psychology of the Kyiv National University of Culture and Arts 